\title{
Effect of potassium and sulphur on nutrient uptake by onion and chilli intercrops in a vertisol
}

\author{
K.S. POORNIMA*, N. MAMATHA AND H.S. RAMESH ${ }^{1}$ \\ Department of Agricultural, Fertilizer Control Laboratory, MANDYA(KARNATAKA) INDIA \\ (Email : poornapavana@gmail.com)
}

\begin{abstract}
A field experiment was conducted during Kharif 2006 on black clay soil to study the effect of potassium and sulphur on onion and chilli intercrops in a vertisol with four levels of potassium $\left(0,50,75\right.$ and $\left.100 \mathrm{~kg} \mathrm{~K}_{2} \mathrm{O} \mathrm{ha}^{-1}\right)$ and three levels of sulphur $\left(0,15\right.$ and $\left.30 \mathrm{~kg} \mathrm{Sha}^{-1}\right)$. The significantly higher uptake of $\mathrm{N}, \mathrm{P}, \mathrm{K}$ and $\mathrm{S}$ by onion plant as well as shoot and fruit portion of chilli were observed with the individual application of potassium @ $100 \mathrm{~kg} \mathrm{~K}_{2} \mathrm{O} \mathrm{ha}^{-1}$ and sulphur @ $30 \mathrm{~kg} \mathrm{~S} \mathrm{ha}^{-1}$.
\end{abstract}

Key Words : Nutrient uptake, Soil sodium, Soil potassium, Bulb, Vertisol, Intercrops

View Point Article : Poornima, K.S., Mamatha, N. and Ramesh, H.S. (2016). Effect of potassium and sulphur on nutrient uptake by onion and chilli intercrops in a vertisol. Internat. J. agric. Sci., 12 (1) : 56-59.

Article History : Received : 15.09.2015; Revised : 25.11.2015; Accepted : 07.12.2015

\footnotetext{
* Author for correspondence : Office of Assistant Registrar of Cooperative Societies, Sahakara Bhavan, SHIMOGA (KARNATAKA) INDIA (Email : mamathadavanagere@gmail.com)

${ }^{1}$ Department of Veterinary Physiology and Biochemistry, Veterinary College, Vinobhanagar, SHIMOGA (KARNATAKA) INDIA

(Email : ramamabhi@gmail.com)
} 